\title{
OPEN Author Correction: Serum Activin A Levels and Renal Outcomes After Coronary Angiography
}

\section{Yi-Lin Tsai, Ruey-Hsing Chou, Ya-Wen Lu, Chung-te Liu, Po-Hsun Huang \& Shing-Jong Lin}

Correction to: Scientific Reports https://doi.org/10.1038/s41598-020-60359-x, published online 25 February 2020

In the original version of this Article, there were errors in Affiliations 2 and 9 which were incorrectly listed as 'Cardiovascular Research Center, Taipei Veterans General Hospital, Taipei, Taiwan' and 'Board of Directors, Taipei Medical University, Taipei, Taiwan', respectively.

The correct affiliations are listed below.

Affiliation 2

Cardiovascular Research Center, National Yang-Ming University, Taipei, Taiwan

Affiliation 9

Taipei Heart Institute, Taipei Medical University, Taipei, Taiwan

These errors have now been corrected in the PDF and HTML versions of the Article, and in the accompanying Supplemental Material.

(i) Open Access This article is licensed under a Creative Commons Attribution 4.0 International License, which permits use, sharing, adaptation, distribution and reproduction in any medium or format, as long as you give appropriate credit to the original author(s) and the source, provide a link to the Creative Commons license, and indicate if changes were made. The images or other third party material in this article are included in the article's Creative Commons license, unless indicated otherwise in a credit line to the material. If material is not included in the article's Creative Commons license and your intended use is not permitted by statutory regulation or exceeds the permitted use, you will need to obtain permission directly from the copyright holder. To view a copy of this license, visit http://creativecommons.org/licenses/by/4.0/.

(c) The Author(s) 2020 